DOE/EA-0973

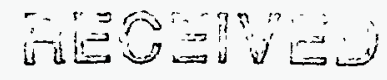

\title{
DEC 171996
}

๑STI

Final Envịronmental Assessment

\section{Gamma Irradiation Facility}

at

Sandia National Laboratories

Albuquerque, New Mexico

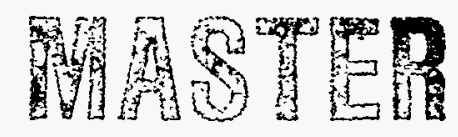

November 1995

DISTAMEUTION OF THIS DOCUMENT IS UNLAMTED

U.S. Department of Energy

Kirtland Area Office

Albuquerque, New Mexico 


\section{DISCLAIMER}

Portions of this document may be illegible in electronic image products. Images are produced from the best available original document. 


\title{
U. S. DEPARTMENT OF ENERGY \\ FINDING OF NO SIGNIFICANT IMPACT
}

\author{
GAMMA IRRADIATION FACILITY \\ at \\ SANDIA NATIONAL LABORATORIES \\ ALBUQUERQUE
}

AGENCY: U. S. DEPARTMENT OF ENERGY

ACTION: FINDING OF NO SIGNIFICANT IMPACT

\section{SUMMARY}

The United States Department of Energy (DOE) has prepared an environmental assessment (EA) on the proposed construction and operation of a new Gamma Irradiation Facility (GIF) at Sandia National Laboratories/New Mexico (SNL/NM). This facility is needed to:

- Enhance capabilities to assure technical excellence in nuclear weapon radiation environments testing, component development, and certification;

- Comply with all applicable ES\&H safeguards, standards, policies, and regulations;

- Reduce personnel radiological exposure to comply with ALARA limits in accordance with DOE orders and standards;

- Consolidate major gamma ray sources into a central, secured area; and

- Reduce operational risks associated with operation of the GIF and LICA in their present locations.

\section{PROPOSED ACTION}

This proposed action provides for the design, construction, and operation of a new GIF located within TA $V$ and the removal of the existing GIF and LICA.

The new GIF building will be a single-story structure located in TA V. It will comprise a central high-bay laboratory with low-bay ancillary spaces. The high-bay laboratory will house three concrete test cells and an 18-foot-deep pool where gamma sources will be stored. Ancillary spaces will include offices, setup laboratories, and mechanical and electrical systems. Building area would total approximately 10,700 gross square feet $(8,300$ net square feet). The proposed action will modernize the GIF and remove it from the ACRR high-bay area. The new GIF will also allow relocation of the Low Intensity Cobalt Array (LICA) from Sandia's densely populated TA I. This will consolidate gamma irradiation sources in a single, dedicated facility.

Improvements to land will include site grading over an area of approximately one quarter acre to provide the elevation required for proper drainage, sidewalks, access roads, and fencing. Utilities will include storm and sanitary sewers, water, communications, and electrical services.

The proposed action includes potential demolition of the gamma shield walls and removal of equipment in the existing GIF and LICA. The shielding pool used by the existing GIF will remain as part of the ACRR facility. Transportation of the existing ${ }^{60}$ Co sources from the 
Finding of No Significant Impact: Gamma Irradiation Facility at Sandia National Laboratories, New Mexico (DOE-EA-0973)

existing LICA and GIF to the new facility is also included in the proposed action. Relocation of the gamma sources to the new GIF will be accomplished by similar techniques to those used to install the sources originally.

\section{ALTERNATIVES CONSIDERED}

\section{No Action}

The no-action alternative would leave the GIF in its present location next to the ACRR in Building 6580. The GIF and ACRR share a high-bay laboratory area, and the limited space around the shielding pools and test cells leads to crowding and difficulties in coordinating experiments between the facilities. This restricts the type and size of experiments that can be safely performed in both areas.

The no-action alternative would leave the LICA in a separate facility in TA I, the most densely populated area at Sandia/New Mexico.

\section{Upgrade Existing Facilities}

Upgrading the existing facilities would involve installing enhanced radiation shielding either around the experimental areas (including the LICA), around areas occupied by personnel, or both to reduce radiation doses under operational and emergency conditions. It would also include upgrading monitoring and control systems in both facilities.

Shielding installed to reduce the exposure to GIF personnel from ACRR operations would further reduce the area available around both facilities for operation and experiment setup. This would place additional limits on the size and type of experiments that can be performed in both facilities.

Upgrading existing facilities would improve shielding at the LICA facility, but would leave it in place in TA I, and would thus not provide for consolidation of the gamma sources.

\section{SUMMARY OF ENVIRONMENTAL IMPACTS}

\section{Resources Considered But Not Discussed in Detail}

Cultural/archaeological resources surveys and threatened/endangered species revealed that no cultural resources or sensitive species were present. The site does not involve any wetlands nor does it lie in a floodplain. The site is owned by DOE, and there are no known conflicts between the action and Federal, regional, state, local, or Indian land use plans, policies, or controls. No existing land uses will be impacted. 
Finding of No Significant Impact: Gamma Irradiation Facility at Sandia National Laboratories, New Mexico (DOE-EA-0973)

\section{Air Quality}

Minor particulate (dust) emissions may be expected as a result of construction activities, but will be controlled by applying water. Exhaust emissions from construction equipment are expected during construction, but will be managed to minimize interference with air intakes for surrounding buildings, etc.

Some ozone would be generated as a result of GIF operations. Total production of ozone in the existing GIF during Fiscal Year 1994 was $400 \mathrm{~g}$. Ozone is released to the atmosphere by diffusion and by forced ventilation of the experimental cells. Ozone decomposes rapidly in air and thus is unlikely to develop hazardous concentrations outside the GIF building. Inside the GIF, exhaust ventilators, ozone detectors, and door interlocks will ensure that personnel cannot enter the cells until ozone levels are within safe limits.

\section{Water Quality}

Water will be used to control dust generated by construction activities. Portable toilets will be used during construction and all waste disposed of in accordance with City of Albuquerque requirements. Storm water incident on the construction site will be contained to prevent construction oils and solvents from traveling off the construction site.

Decommissioning the LICA facility after moving its radiation sources from TA I to the new GIF will require disposing of approximately 36,000 gallons of water from the LICA shielding pool. Small quantities of ${ }^{137} \mathrm{Cs}$ and ${ }^{60} \mathrm{Co}$ have been released into this water in the past, although most of the radioactive contaminants were captured by the ion exchange resins used to purify the water. The resins would be disposed of as solid, low-level radioactive waste in a permitted, off-site disposal facility. The water will be monitored for residual radioactivity and disposed of in accordance with current regulations. If the radiation levels met the current standards for the sanitary sewer system, the water will be disposed of as sanitary sewerage. If, on the other hand, the water does not meet standards for disposal in the sanitary sewer, it will be treated in an appropriate manner (e.g. the water would be evaporated or solidified), and the radioactive material disposed of as solid radioactive waste.

The design of the GIF shielding pool make-up water system includes improved level monitoring and shut-off valve designs that preclude the possibility of overfilling the pool. In addition, all drains in the facility will be connected to the Liquid Effluent Control System (LECS). The LECS is a central facility consisting of containment tanks that capture all liquid effluent from connected facilities. Radiation detectors monitor the effluent in the containment tanks. If the monitors detect presence of radioactive material, the LECS prevents the effluent from entering the sanitary sewer system. Thus all wastewater discharges from the GIF will be monitored before leaving Sandia property. 


\section{Soils and Seismology}

Since the bearing capacity of the soils at the GIF site is sensitive to water content, a combination of spread-type footings at least 20 feet below the surface and drilled, cast-inplace concrete piers would be used in the building foundation (AGRA 1992). In addition, site grading would be designed to keep water away from the building.

The new GIF will be designed according to the applicable standards to prevent damage by seismic events.

\section{Impacts to Workers and the Public}

The only source of potential impacts resulting from the proposed action is the radiation dose that may be received by workers and/or the public. Under normal operations no dose to personnel inside or outside the facility will be detectable. The collective dose due to accidental radiation exposure is lower in the proposed action than in the existing GIF due to the smaller number of operational personnel in the area. This is because the new GIF will be removed from the vicinity of the ACRR and its operating personnel.

In the event of an accident, radiation area monitors (RAMs) located on the interior walls and on the facility walls across from the access doors to the cells would activate alarms, warning personnel of the accident so they could evacuate to a safe area. Radiation would not be released to the environment, since the radioactive material would remain inside the facility.

\section{DETERMINATION}

In accordance with the Council on Environmental Quality (CEQ) requirements contained in 40 CFR parts 1500-1508, the EA examined the potential environmental impacts of the proposed GIF and discussed potential alternatives. Based on the analyses in the EA, DOE determined that the proposed action does not constitute a major Federal action significantly affecting the quality of the human environment within the meaning of the National Environmental Policy Act (NEPA) of 1969, and CEO regulations at 40 CFR 1508.18 and 1508.27. Therefore, an environmental impact statement (EIS) is not required, and DOE is issuing this Finding of No Significant Impact (FONSI).

For a detailed description of the proposed action and its environmental consequences, refer to the EA. 
Finding of No Significant Impact: DOE-EA-0973

(505) $845-5541$

FOR FURTHER INFORMATION ON THE NEPA REVIEW PROCESS, CONTACT:

Jeff Robbins, NEPA Compliance Officer

Department of Energy Albuquerque Operations Office

P. O. Box 5400

Albuquerque, NM 87185,5400

(505) $845-4426$

Issued this 16 day of 1995.

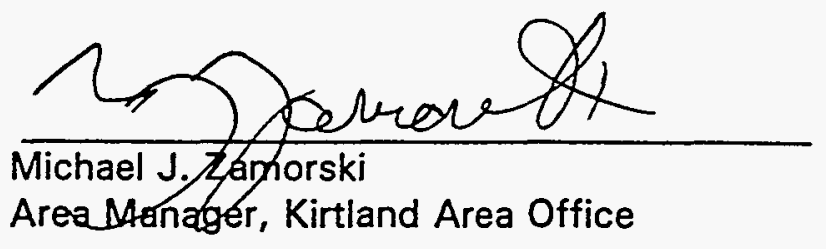

5 


\section{TABLE OF CONTENTS}

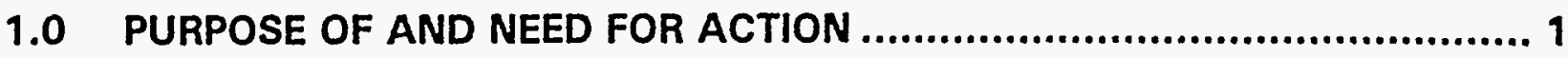

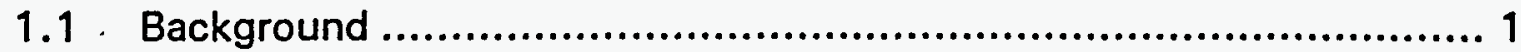

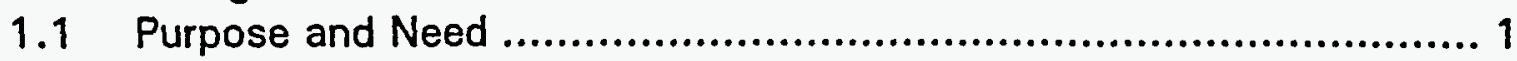

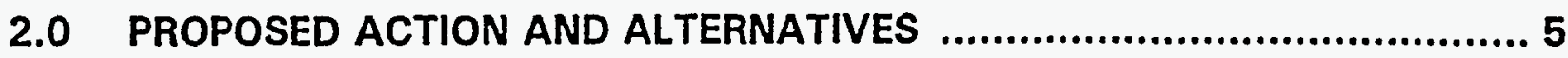

2.1 Proposed Action............................................................... 5

2.1.1 Pre-Operational Activities ............................................. 5

2.1.2 Normal Operations...................................................... 6

2.2 Alternative 1: No Action....................................................11

2.3 Alternative 2: Upgrade Existing Facilities ..................................12

2.4 Alternative Considered But Eliminated From Detailed Analysis..........13

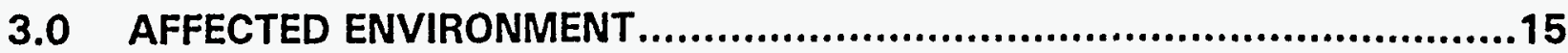

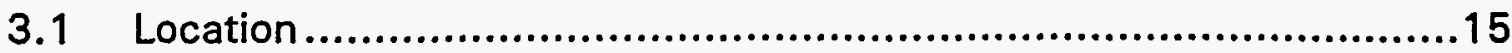

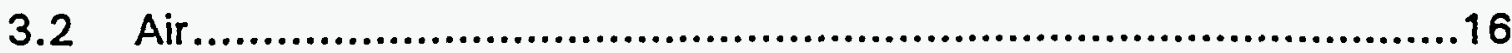

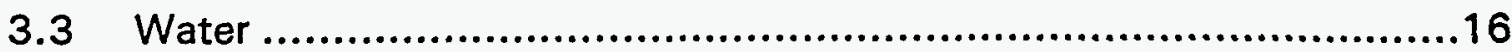

3.4 Soils and Seismology .......................................................16

3.5 Biological Resources ...................................................17

3.6 Worker Environment ......................................................18

3.7 Archaeological and Historical Resources ...................................18

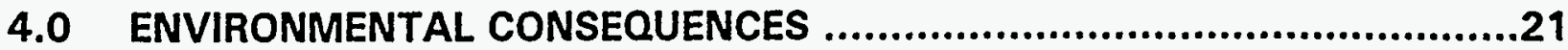

4.1 Proposed Action ...........................................................21

4.1.1 Pre-Operational Activities ............................................21

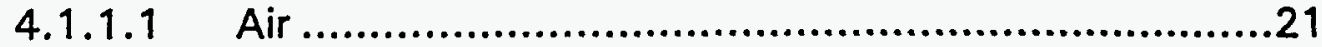

4.1.1.2 Water .....................................................21

4.1.1.3 Soils and Seismology ......................................22

4.1.1.4 Impacts to Workers.........................................22

4.1.1.5 Impacts to the Public........................................23

4.1.2 Normal Operations......................................................23

4.1.2.1 Air .........................................................23

4.1.2.2 Water .......................................................23

4.1.2.3 Soils and Seismology .......................................23

4.1.2.4 Impacts to Workers...........................................23

4.1.2.5 Impacts to the Public.........................................25 


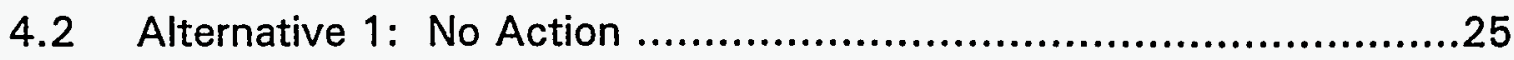

4.2.1 Air.....................................................................25

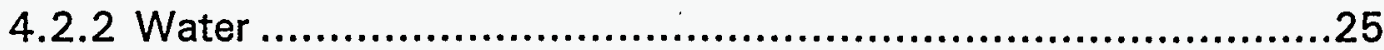

4.2.3 Soils and Seismology ...............................................25

4.2.4 Impacts to Workers .................................................26

4.2.5 Impacts to the Public ............................................27

4.3 Alternative 2: Upgrade Existing Facilities ...............................27

4.3.1 Pre-Operational Activities ..........................................27

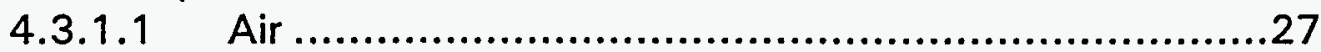

4.3.1.2 Water.......................................................28

4.3.1.3 Soils and Seismology .....................................28

4.3.1.4 Impacts to Workers and the Public ......................28

4.3.2 Normal Operations...................................................28

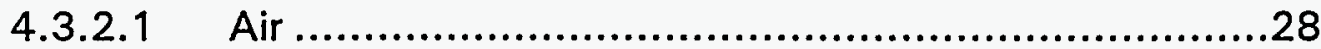

4.3.2.2 Water ......................................................28

4.3.2.3 Soils and Seismology ....................................28

4.3.2.4 Impacts to Workers........................................28

4.3.2.5 Impacts to the Public .......................................29

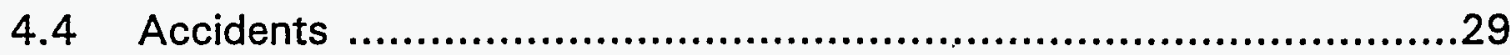

4.4.1 Worker Exposure to Ozone ..........................................29

4.4.2 Worker Exposure to Radiation ........................................30

4.4.3 Source Rupture .........................................................31

4.4.4 Accidents Considered But Not Discussed In Detail.................32

4.5 Cumulative Impacts ........................................................33

4.5.1. Cumulative Operations Impact for the Public......................33

4.5.2. Cumulative Operations Impact for GIF Workers ....................33

4.5.3. Cumulative Impact on the Environment ............................34

4.5.4. Summary of Cumulative Impacts......................................35

4.6 Environmental Justice .......................................................35

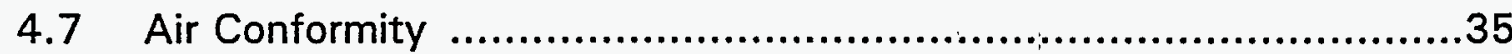

5.0 PERSONS AND AGENCIES CONSULTED ........................................37

6.0 LIST OF ACRONYMS AND ABBREVIATIONS ..................................39

7.0 REFERENCES 
TABLE OF CONTENTS (Continued)

\section{LIST OF TABLES}

Table

3-1 Threatened and Endangered Species on KAFB

Page

4-1 Worker Doses Under the Proposed Action .18

4-2 Worker Doses Under the No-Action Alternative

4-3 Worker Doses under the Upgrade Facilities Alternative.....

4-4 Summary of Cumulative Impacts ..................................................35

\section{LIST OF FIGURES}

Figure

Page

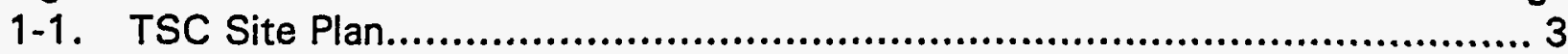

2-1. GIF Conceptual Floor Plan........................................................ 6

2-2. ACRR and GIF Layout, No-Action Alternative ...................................12

3-1. Proposed Site Location.............................................................15 


\subsection{PURPOSE OF AND NEED FOR ACTION}

\subsection{Background}

The existing Gamma Irradiation Facility (GIF) is located at Sandia National Laboratories/New Mexico (SNL/NM) in Tech Area (TA) V, adjacent to the Annular Core Research Reactor (ACRR), as shown in Figure 1-1. SNL/NM is located within the boundaries of Kirtland Air Force Base (KAFB). The facilities at TA $V$ are unique in providing high-fidelity simulation of nuclear radiation environments for warhead and component testing. It is essential that these facilities be preserved to maintain the nation's ability to demonstrate viable weapon component response to radiation; accommodate the radiation environment testing requirements of new and expanded non-weapons research, development and production programs; and provide other unique services requiring the use of nuclear facilities. Moreover, these radiation testing facilities must be modernized to meet evolving operational, safety, and environmental requirements.

Consistent with these requirements and in response to previous safety reviews, Sandia has established a policy ("Tech Area V Long Range Development Plan", August 29,1988 ) to locate all high-activity radiation sources within TA $V$ in order to satisfy Department of Energy (DOE) orders and standards, which require radiation exposure levels for non-operational personnel to be as low as reasonably achievable (ALARA).

\subsection{Purpose and Need}

Current conditions at the GIF are crowded, and worker exposures to radiation resulting from GIF operations, while safe, are higher than they would be if the GIF were not co-located with the Annular Core Research Reactor and related operations.

The size of the GIF test cells is limited and cannot be increased without major modifications to the building. The limited space around the shielding pools and test cells leads to crowding and difficulties in coordinating experiments between the facilities. This restricts the type and size of experiments that can be safely performed in both areas. Operations will require more space, larger sources, and modernization to enhance the safety of operations personnel and to increase flexibility for current and emerging missions. The proposed action would contribute to the health and safety of personnel by reducing the potential for radiological exposure to GIF personnel from the ACRR source term. It would consolidate the existing GIF and Low intensity Cobalt Array (LICA) into a new facility with modern environmental, health, and safety provisions. The purpose of the proposed action includes the following: 
- Enhance capabilities to assure technical excellence in nuclear weapon radiation environments testing, component development, and certification;

- Comply with all applicable Environment, Safety and Health (ES\&H) safeguards, standards, policies, and regulations;

- Reduce risk to non-operational personnel;

- Consolidate major gamma ray sources into a central, secured area; and

- Reduce operational risks associated with operation of large radiation sources.

The proposed action would also provide a modern facility to satisfy Sandia's need for sustained gamma environment testing well into the next century. These continuing and emerging needs include testing programs involving materials for spacecraft, civilian nuclear power, nuclear waste disposal, and other civilian programs, as well as prudent maintenance of the nuclear weapons stockpile. To satisfy these missions, the facility would be designed to irradiate materials over a wide range of dose rates and total dose. This requires the acquisition of additional radiation sources near the start of the facility operation and replacement sources over the lifetime of the GIF. ${ }^{60}$ Co has a 5.27 year half-life and therefore has a limited useful life of approximately 10 to 20 years. As part of the staging of the GIF sources, new sources would be initially placed in high-level irradiation assemblies. As sources decay, they would be moved to medium level, and subsequently low-level irradiation assemblies. This extends the useful life of each source. Some sources would inevitably decay to the level where they are no longer useful. These sources would be shipped out for reuse or shipped for disposal. Even with this staging approach, it is estimated that up to $185 \mathrm{PBq}(5,000 \mathrm{kCi})$ of new ${ }^{60}$ Co sources would be required over the 40 -year projected lifetime of the GIF. No more than $55.5 \mathrm{PBq}(1,500 \mathrm{kCi})$ of ${ }^{60} \mathrm{Co}$ would be present in the facility at any time. Other smaller sealed sources such as Cesium-137 may also be used in the GIF, but their total inventory would be much less than the ${ }^{60} \mathrm{Co}$ inventory. 


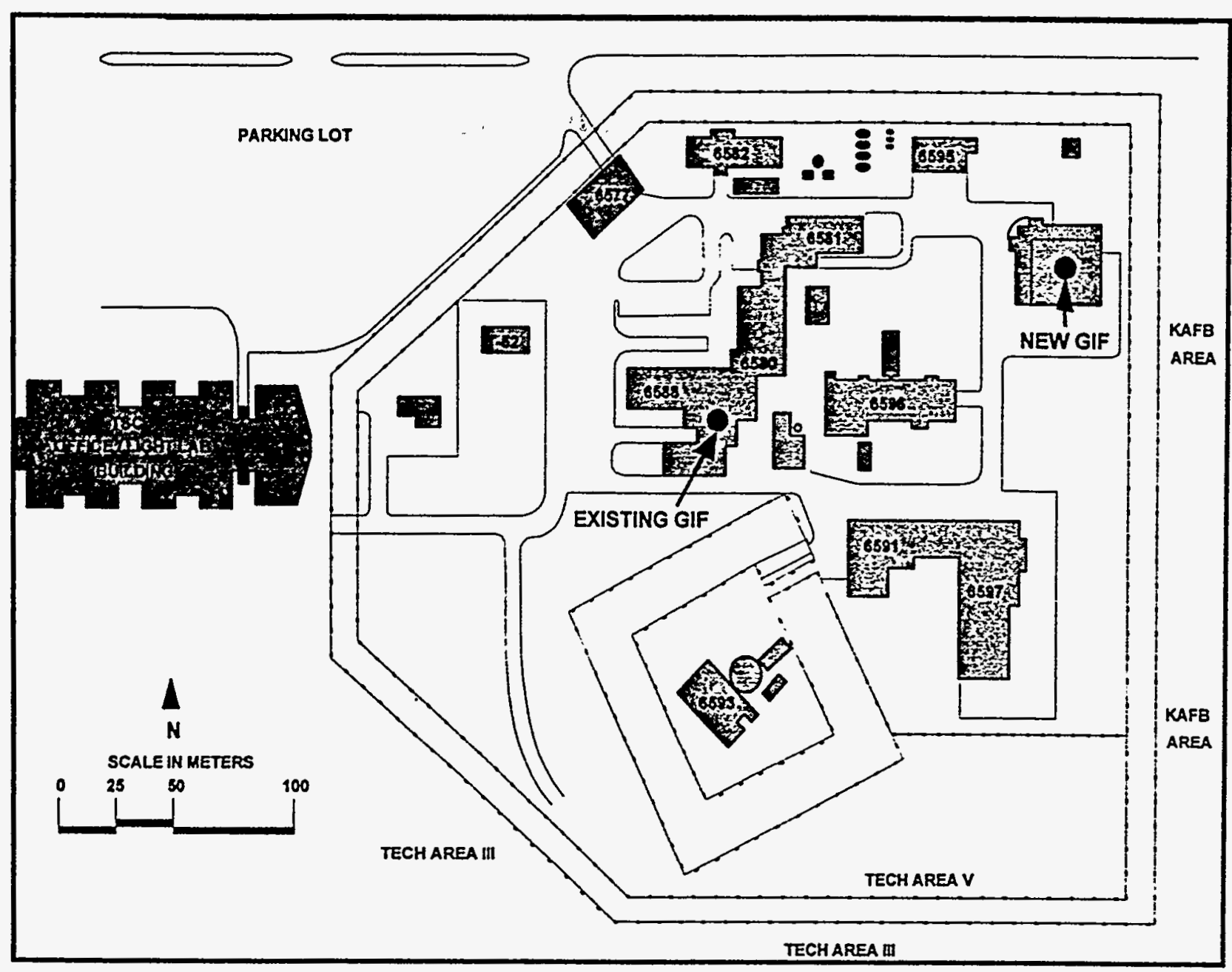

Figure 1-1. TA V Site Plan 
This page intentionally left blank.

DOE/EA - 0973 


\subsection{PROPOSED ACTION AND ALTERNATIVES}

This environmental assessment discusses in detail three alternatives: 1) the proposed action; 2) the no action alternative; and 3) upgrading existing facilities.

\subsection{Proposed Action}

This proposed action provides for the design, construction, and operation of a new GIF located within TA V; potential removal of the existing GIF; and relocation of the LICA to the new GIF location.

\subsubsection{Pre-Operational Activities}

Improvements to land would include site grading over an area of approximately one acre to provide the elevation required for proper drainage, sidewalks, access roads, and fencing. Utilities would include storm and sanitary sewers, water, communications, and electrical services. Water would be used to control dust generated by construction activities. Portable toilets would be used during construction and all waste would be disposed of in accordance with City of Albuquerque requirements. Storm water would be contained on the construction site to prevent dust and other construction-related substances from traveling off the construction site.

The new GIF would be composed of a central high-bay laboratory with low-bay ancillary spaces (Figure 2-1). The high-bay laboratory would house three concrete test cells and an 18-foot-deep pool where gamma sources would be stored. The walls and floor of the pool would be constructed of reinforced concrete approximately $0.3 \mathrm{~m}$ (12 inches) thick, with a $0.5 \mathrm{~cm}(0.2$ inch) thick, continuouslywelded stainless steel liner (Boldt 1995). Ancillary spaces would include offices, setup laboratories, and mechanical and electrical systems. Building area would total approximately 12,300 gross square feet. The proposed action would modernize the GIF and remove it from the ACRR high-bay area. This would relieve congestion around both the GIF and the ACRR, reduce the potential of exposing operating staff to radiation, facilitate personnel evacuation in an emergency, and free space adjacent to the ACRR for experimental work. The new GIF would also allow relocation of the LICA from Sandia's densely populated TA 1. This would consolidate gamma irradiation sources in a single, dedicated facility, reducing the potential for radiation exposure of personnel.

The new cell would use the existing GIF cobalt gamma sources and additional new sources in larger, shielded rooms, which would provide the capability for entire system tests. These tests are prohibited by the size and radiation source strength of the current facility. Shielding and other provisions would be designed to accommodate source strengths up to $9.3 \mathrm{PBq}(250 \mathrm{kCi})$ in the small cells and 18.5 PBq $(500 \mathrm{kCi})$ in the large cell. The pool is designed to hold a total capacity of $55.5 \mathrm{PBq}(1,500 \mathrm{kCi})$. 
The relocated LICA would share the GIF high bay and would provide greater capacity for low-dose-rate experiments, which are increasingly emphasized in current research and development programs.

The proposed action includes the possible demolition of the gamma shield walls and removal of equipment in the existing GIF and LICA. The decision to demolish the existing GIF shield walls will be made based on projections of future experimental needs. The shielding pool used by the existing GIF would remain as part of the ACRR facility. Decommissioning the LICA facility after its radiation sources have been moved from TA I to the new GIF would require disposing of twelve 15-gallon canisters of ion exchange resins. These would be managed as solid, low-level radioactive waste.

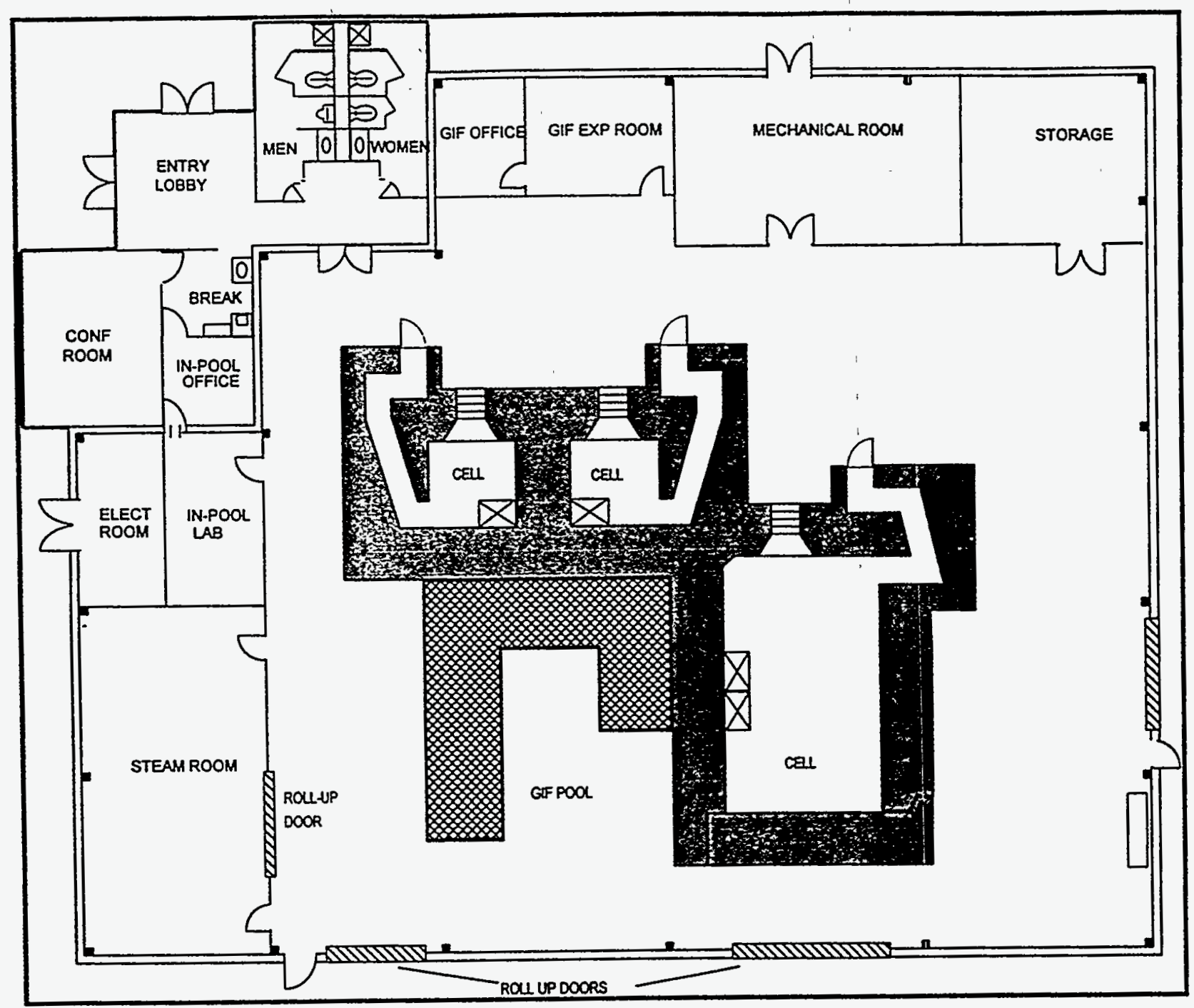

Figure 2-1. GIF Conceptual Floor Plan 
Decommissioning the LICA facility after moving its radiation sources from TA I to the new GIF would require disposing of approximately 36,000 gallons of water from the LICA shielding pool. Trace quantities of ${ }^{137} \mathrm{Cs}$ and ${ }^{60} \mathrm{Co}$, introduced while transferring casks into the pool, have been detected in this water in the past. Most of the radioactive contaminants were captured by the ion exchange resins used to purify the water. The resins would be removed and stored on site pending evaluation and appropriate disposition. Such disposition might include free release if contamination is below levels of regulatory concern or disposal as radioactive waste in a permitted, off-site disposal facility. The water would be monitored for residual radioactivity and disposed of in accordance with current regulations. If the radiation levels met the current standards for the sanitary sewer system, the water would be disposed of as sanitary sewage. If, on the other hand, the water did not meet standards for disposal in the sanitary sewers, it would be treated in an appropriate manner (e.g. the water would be evaporated, processed through ionexchange resins, or solidified), and the remaining radioactive material disposed of as solid radioactive waste.

Transportation of the existing ${ }^{60}$ Co sources from the existing LICA to the new GIF is included in the proposed action. Relocation of the LICA gamma sources to the new GIF would be accomplished by similar techniques to those used to install the LICA sources at their current location. The sources would be transferred from their mountings to a Department of Transportation (DOT) approved shipping cask by remote handling apparatus under water in the shield pools. When the casks are loaded and sealed, they would be removed from the pool, inspected for proper seal and radiation leakage, and loaded on a transport vehicle for shipping to the new site. The transport vehicle would carry placards identifying the material being transported in accordance with Sandia policy (SNL 1989). The vehicle would be equipped with emergency communications and radiation monitoring equipment. Escorts would accompany the vehicle from loading to unloading. In the new facility, the shipping cask would be submerged in the shield pool and the sources moved to their mountings by remote handling equipment. LICA sources would be placed in the pool at the lower left hand corner of the pool as shown in Figure 2-1.

Transportation of the existing GIF sources to the new GIF facility would occur entirely within TA-V over driveways in the area. The distance between the facilities is approximately 200 meters (656 feet). No KAFB or general public roadways would be used in the transfer operation. The operations is governed by DOEapproved Sandia manuals for on-site transportation. A shielded cask would be acquired for transfer of a few ${ }^{60} \mathrm{Co}$ sources in a single shipment. The procedures for loading, transferring, and unloading the sources are similar to those presented for the LICA sources.

Transportation of the new ${ }^{60} \mathrm{Co}$ sources would be performed by the manufacturer of the new sources using Department of Transportation (DOT) approved shipping casks. Regulatory compliance for the shipment of radioactive materials would be 
the responsibility of the manufacturer. One potential manufacturer of gamma sources is the Atomic Energy of Canada limited (AECL) Industries which designed and fueled 71 of the world's 132 large irradiators (total ${ }^{60} \mathrm{Co}$ inventory of 106,000 $\mathrm{kCi}$ in 1986).

\section{1 .2 Normal Operations}

The GIF and LICA are used to conduct experiments to evaluate the response of test objects to radioactive environments. In the GIF, a test object is placed in the GIF cell, and a radioactive source is raised into the cell from the GIF pool. At the conclusion of the irradiation, the source is lowered back into the pool and the test object is removed and examined to assess the effects of exposure to radiation. At the LICA, test objects are lowered into a position adjacent to the source.

Facilities involved in the GIF operations would include the following:

- In-Cell Dry Irradiation Facilities: The in-cell facilities are large, dry, shielded rooms in which irradiations are performed with a high intensity gamma-ray source located in the room.

- In-Pool Wet Irradiation Facilities: In the in-pool facilities, radioactive sources are held in an irradiation fixture in a deep pool of water where they remain stationary. Experiment canisters containing test units are immersed in the pool and positioned in preset locations in the irradiation fixture.

- Shepard Irradiation Facilities (possible future addition): A Shepard cell is a self-contained, dry irradiator which contains sources and an irradiation cavity in a small shielded cask. A traveling, shielded drawer provides access for test units to the irradiation chamber.

The routine operation of these facilities is performed on an as-needed basis for irradiation of experimental test units with ionizing gamma (high energy photon) radiation. The types of experiments performed cover many disciplines as demonstrated in the following list of anticipated experiments for the irradiation facilities:

In-Cell Irradiation

- Electronic component hardness, survivability, and certification tests for military and commercial applications.

- Integral hardness test units such as military vehicles or space satellites.

- Radiation effects on material properties.

- Radiation effects on organic materials.

- Mixed environment testing (e.g. steam and radiation, heat and radiation, etc.). 
In-Pool Irradiation

- Simultaneous thermal and radiation effects studies on nuclear reactor components.

- Weapon components for degradation testing.

- Material/component testing for nuclear reactor accident tests.

- Electronic component certification.

Only one person would occupy and operate the GIF on a full-time basis, although other personnel would have access to the facility from time to time to set-up, monitor, and remove experiments. Each individual of this class of workers would typically be in the GIF fewer than 100 hours per year. Some increase in the number of experiments may occur as a result of the additional capacity of the facility; however, no substantial increase in activity or emissions is expected.

Operation of the GIF is expected to generate a small quantity of ozone (approximately 400 grams [14 ounces] per year). The amount produced over any given period would vary widely according to the size of the source and length of exposure, both of which are under the control of the GIF operators.

The effect of ozone on indoor air quality depends on measures taken to ventilate the exposure cells and to delay entry to the cells after irradiation. In the proposed action, exhaust ventilators, ozone detectors and door interlocks would ensure that personnel could not enter the cells until ozone levels were within safe limits. When the door to the cell is closed, the ventilation system for the cell would maintain a negative pressure relative to the outside and would provide more than 30 air changes per hour of operation. A timer would require a delay of 10 minutes between removing the source from the cell and opening the cell door.

The current GIF is connected to the Tech Area V sanitary sewer and storm sewer systems. The sanitary sewer handles effluent from all plumbing fixtures, such as drinking fountains, water closets, lavatories, urinals, janitor closets, and some floor drains. Operation of the system is not subject to any categorical pretreatment standards under the Clean Water Act. The existing TA V sanitary system is connected to the City of Albuquerque publicly-owned treatment works (POTW).

All liquid effluent potentially containing radioactive constituents from the GIF (overflow from the shield pool, floor drains in experimental areas, etc.) is collected separately and conducted to the TA V Liquid Effluent Control System (LECS). The LECS is a facility located in an adjacent area of TA $V$ and consists of buffer tanks that capture all liquid effluent from connected facilities and radiation detectors that monitor the facility. Effluent collected in the tanks is routinely sampled and evaluated for $\mathrm{pH}$ and the presence of radiological contaminants. If the effluent meets standards for disposal in the sanitary sewer, it is released to the POTW. If, on the other hand, elevated levels of radioactive constituents are detected in the effluent, the affected tank is isolated from the system. In this event, the effluent 
would be processed through ion-exchange resins and the resulting radioactive material disposed of as radioactive waste.

Like the existing GIF, the proposed GIF would be connected to the existing Tech Area $V$ sanitary sewer and storm sewer systems. The sanitary sewer would handle effluent only from domestic plumbing fixtures, such as drinking fountains, water closets, lavatories, urinals, janitor closets, and floor drains outside the experimental areas. Operation of the system is not subject to any categorical pretreatment standards under the Clean Wațer Act. The existing TA V sanitary system is connected to the City of Albuquerque POTW.

The design of the pool make-up water system includes improved level monitoring and make-up water valve designs that would preclude the possibility of overfilling the pool. Accidental splashes and spills of pool water would drain to the existing LECS. All wastewater discharges from the GIF other than sanitary sewage would be monitored before leaving the TA $V$ boundary.

The existing LICA facility in TA I is not connected to a LECS. No releases of shield pool water have been reported over the life of the facility.

Hazardous chemicals would not be used in the GIF or LICA except as components in experimental articles and in small quantities, generally less than a liter, for light maintenance, electronic fabrication, and repair procedures. The handling, use, storage, and disposal of other chemicals in the GIF (ion-exchange resins for water purification, detergents for general cleaning, etc.) would follow instructions in the Sandia ES\&H Manual (SNL, 1991a), Guidelines for Wastewater Discharges for Sandia National Laboratories (SNL, 1991b), and Material Safety Data Sheets (MSDSs). These instructions are intended to prevent contamination of sewer effluent by hazardous materials. All hazardous materials would be stored and handled in accordance with product-specific MSDSs. All employees at Sandia/New Mexico receive training on chemical hazards in accordance with 29 CFR

1900.1200. Spill-response and first-aid materials and information are also provided in accordance with MSDS requirements.

All new activities using chemicals would be governed by activity-specific standard operating procedures (SOPs) containing instructions for safe use of chemicals and for response to spills or other accidental exposures. Chemicals would be segregated for storage, with flammable materials stored in flammable storage cabinets. Gas cylinders would be housed in a cabinet outside of the facility with gases piped inside for use.

Sandia regulations prohibit discharge of hazardous chemicals into the sanitary sewer system. Such chemicals are collected and disposed of in accordance with all applicable laws and standards by the Sandia Hazardous Waste Management Program. 


\subsection{Alternative 1: No Action}

The no-action alternative would leave the GIF in its present location next to the ACRR in Building 6580. The GIF and ACRR share a high-bay laboratory area as shown in Figure 2-2. Operations at the GIF would be similar to those described in the proposed action, but would be conducted in the current location. The no-action alternative would leave the LICA in a separate facility in TA I, the most densely populated area at Sandia/New Mexico.

All LICA experiments and almost all GIF experiments use non-radioactive targets, which do not become radioactive as a result of the gamma irradiation in the GIF. Some targets may be radioactive as a result of previous neutron irradiation (e.g., at a nuclear reactor) or because they are radioactive in their naturally occurring state (e.g., uranium metal or uranium ore). These targets do not become more radioactive as a result of GIF irradiation. Release of radioactive materials from the targets is extremely unlikely as long as the equipment containing them remains intact. Since the test articles are typically weapons, reactor components, and military equipment, which are designed to withstand severe environments, the probability of severe damage to the articles is low. The physical or chemical state of materials in the test articles may change as a result of intentional exposure of the target to heat sources, chemicals, etc., while in the GIF.

Similarly, building materials and equipment do not become radioactive upon exposure to gamma radiation, and there is no lingering radiation after the sources are removed from the cells.

No construction activities would be conducted, nor would any sources be relocated from either the GIF or LICA to a new location in TA V. 


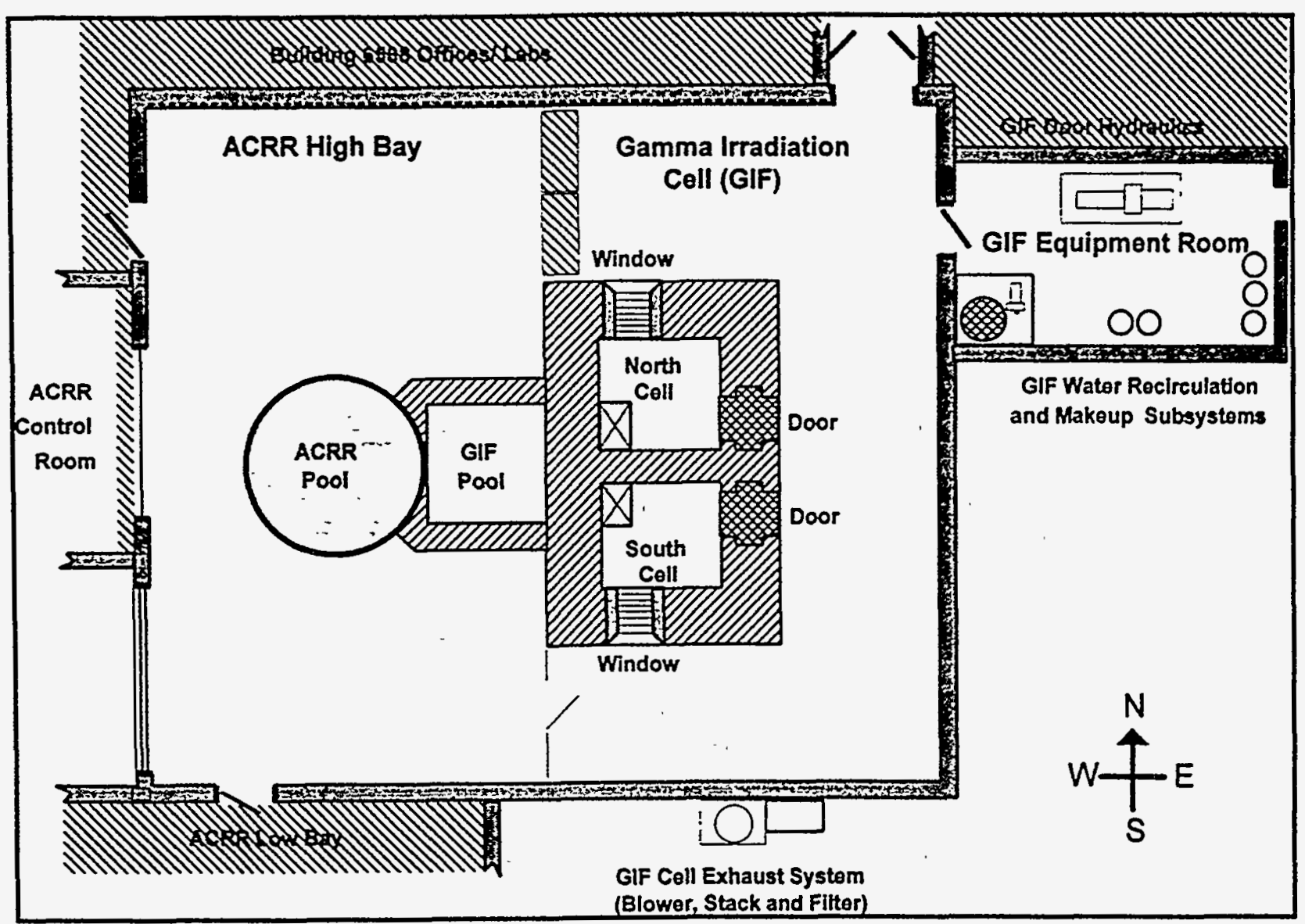

Figure 2-2. ACRR and GIF Layout, No Action Alternative

\subsection{Alternative 2: Upgrade Existing Facilities}

Upgrading the existing facilities would involve installing radiation shielding either around the experimental areas (including the LICA), around areas occupied by personnel, or both to reduce radiation doses under operational and emergency conditions. It would also include upgrading monitoring and control systems in both facilities.

Shielding installed to reduce the exposure to GIF personnel from ACRR operations would further reduce the area available around both facilities for operation and experiment setup. This would place additional limits on the size and type of experiments that can be performed in both facilities.

Upgrading existing facilities would improve shielding at the LICA facility, but would leave it in place in TA I, and would thus not provide for consolidation of the gamma sources. 


\subsection{Alternative Considered But Eliminated From Detailed Analysis}

Another alternative would be to construct the GIF at another site on Kirtland Air Force Base (KAFB). 'This alternative would move the GIF to another, remote site on KAFB outside TA V. This would meet the project objective of consolidating sources and removing LICA from TA I, but would not contribute toward locating large radiation sources inside TA V. This goal of the Sandia ES\&H Long Range Plan is intended to place the potentially most hazardous radiation sources under the tight security and safety control provided by the TA V security perimeter. Duplicating the TA V level of security and access control would be expensive.

Locating the facility in DOE-owned property in Tech Areas I, II, III, or IV is complicated by the lack of suitable sites. Tech Areas I and IV are fully developed, and TA III is almost completely covered by safety exclusion zones associated with the remote testing sites located there. Sites are available around TA II, but offer no obvious environmental or safety advantages over TA V. Safety and environmental planning for TA II sites is complicated by their proximity to the flight path for the main runway at Albuquerque International Airport. 
This page intentionally left blank.

DOE/EA - 0973 


\subsection{AFFECTED ENVIRONMENT}

\subsection{Location}

SNL/NM lies approximately 6-1/2 miles east of downtown Albuquerque, New Mexico, and extends south from approximately one mile south of Central Avenue and two miles south of Interstate 40 (see Figure 3-1). The overall location is part of a high, arid plateau in the foothills of the Manzano Mountains. The plateau slopes gently to the west to the Rio Grande.

SNL/NM is essentially surrounded KAFB and has joint-use agreements on some portions of the U. S. Air Force's 24,500 acre property. An additional 22,500-acre area to the east of KAFB has been by the Forest Service for the exclusive use of KAFB and DOE. Areas to the west and south are bounded by land belonging to the State of New Mexico and Isleta Pueblo.

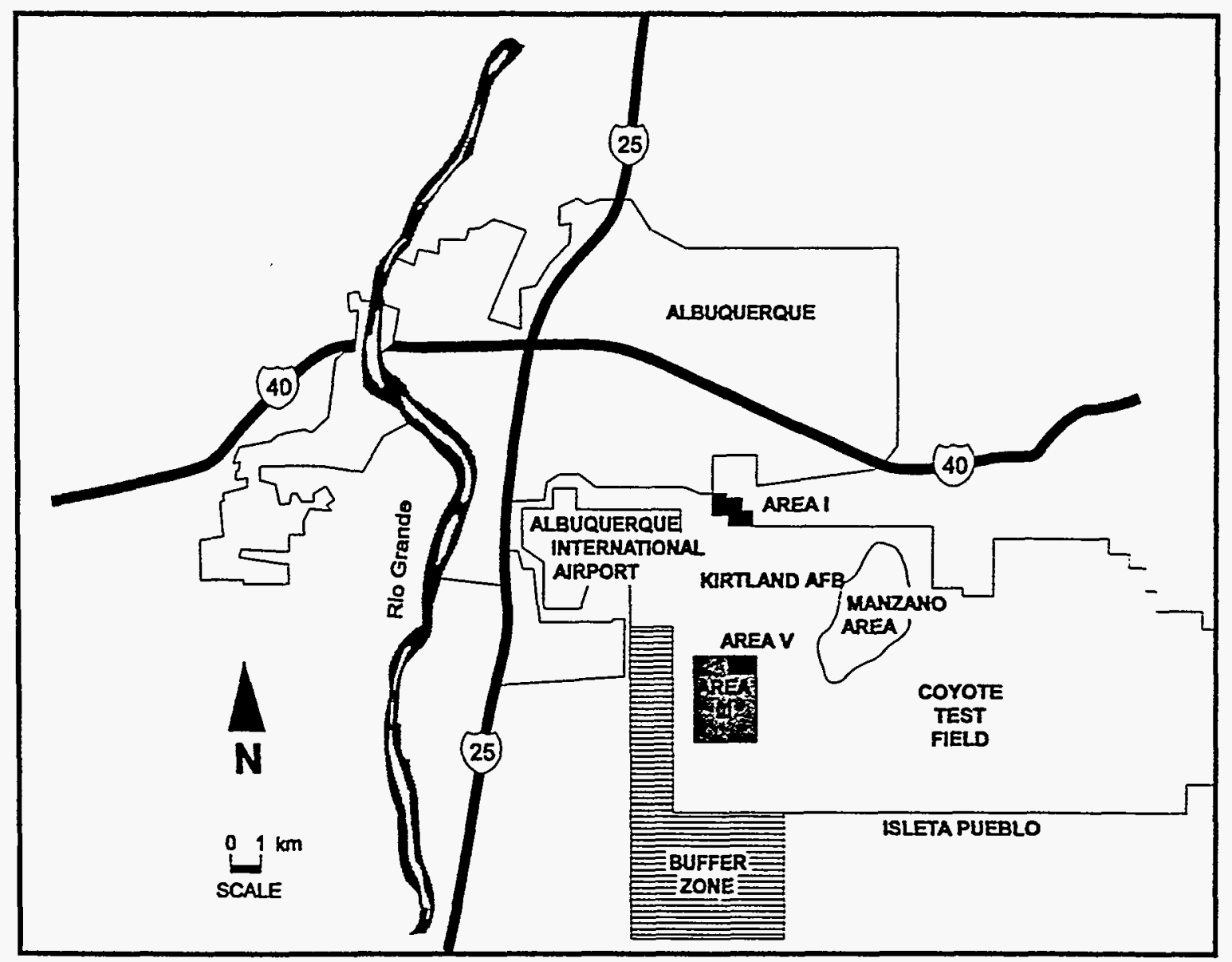

Figure 3-1. Proposed Site Location. 
Additional geographical, meteorological, geological, seismological, and hydrological characteristics of SNL/NM including the proposed GIF site and the surrounding vicinity are described in detail in an environmental impact assessment (ERDA 1977) and in the Sandia National Laboratories, New Mexico Environmental Baseline Update (SNL 1993).

The proposed GIF site is located within TA V and is completely enclosed by the TA $V$ security perimeter. The entire TA $V$ area has been heavily disturbed by previous activities.

\subsection{Air}

Air quality at the proposed site is strongly influenced by the presence of the Albuquerque metropolitan area to the north and west. SNL/NM is situated on the east side of the Albuquerque Basin, which is protected by the Sandia and Manzano Mountains on the east and the West Mesa on the west. This reduces much of the air flow that would carry air pollution away from the metropolitan area (NMAQB 1984). Temperature inversions are common in the Albuquerque Basin, especially on winter nights, but usually dissipate as soon as the sun begins to heat the ground surface in the morning.

Bernalillo County is designated as a non-attainment area for carbon monoxide under the provisions of the Clean Air Act and regulations promulgated thereunder. Accordingly, DOE must determine whether the project is in conformance with the State Implementation Plan, as required by 40 CFR Part 51.

\subsection{Water}

Average annual precipitation in the area of SNL/NM is about 20 to 21 centimeters (8.3 inches). No bodies of surface water, wetlands, or floodplains are present at the proposed site or alternative sites. The proposed site is essentially level. Except during heavy storms, most precipitation percolates into the permeable soil and evaporates or transpires (USGS 1977). During heavy precipitation, sheet flows carry water into natural and artificial drainage channels, which lead to Tijeras Arroyo, approximately one mile north of the proposed site. Tijeras Arroyo is an ephemeral tributary of the Rio Grande.

Depth to ground water at SNL/NM is about 150 meters (500 feet).

\subsection{Soils and Seismology}

Soil characteristics were determined by boring seven test holes 40 to 75 feet below existing grade. The subsurface soil profile is characterized by silty sands, sands, and gravels to the full extent of the borings. No free groundwater was encountered in any of the boreholes. Moisture content of the soils is low. 
SNL/NM is located in Seismic Risk Zone 2, a zone of moderate seismic activity. Earthquakes with horizontal accelerations exceeding $0.22 \mathrm{~g}(0.22$ times the force of gravity) could occur with an probability of 0.001 (UCRL 1990). This ground acceleration corresponds to a rating of 5.0 on the Richter Scale. Three earthquakes measuring approximately 4.7 on the Richter Scale have been recorded in the Albuquerque/Socorro area during the past 25 years. No buildings or facilities at SNL/NM were damaged by these earthquakes (Sanford 1972).

\subsection{Biological Resources}

The site proposed for construction and relocation of the GIF is located within the security area of TA V. Nearly all of the ground at the proposed construction site is naturally vegetated with grasses. Several weedy species, such as Russian thistle (Salsola kali), summer cypress (Kochia scoparia), and threeawn (Aristida), are also present.

Consultation was undertaken with the U. S. Fish and Wildlife Service, the New Mexico Department of Fish and Game, and the State of New Mexico Energy, Minerals, and Natural Resources Department by letters dated April 9, 1992. These letters requested lists of species listed by state and federal agencies or proposed to be listed as threatened or endangered. The area under consideration in that consultation was substantially larger than the proposed GIF site, including 2,000 acres of grassland encompassing all of TA III lof which TA V is in the extreme northeast corner) and other surrounding lands. Table 3-1 lists plant and animal species potentially occurring on KAFB that are categorized as threatened, endangered, or candidate species on state or federal lists.

A thorough biological survey was conducted during the summer and early fall of 1992 for an area encompassing all of TA III and some adjacent areas by biologists Dr. Robert M. Sullivan and Mr. Paul J. Knight (Sullivan 1992). During September 1992, the survey team examined the proposed site for construction of the GIF building. Their conclusions as related to protected species are described in Chapter 4, Environmental Consequences. 


\begin{tabular}{|l|l|}
\hline Common Name & Scientific Name \\
\hline Animals & \\
\hline Bald Eagle & \\
\hline Common black hawk & Haliaeetus leucocephalus \\
\hline Peregrine falcon & Buteogallus anthracinus \\
\hline Whopping crane & Falco peregrinus \\
\hline Willow flycatcher (southwestern) & Grus americana \\
\hline Meadow jumping mouse & Empidonax traillii \\
\hline & Zapus hudsonius \\
\hline Plants & \\
\hline Gramma grass cactus & \\
\hline White visnagita cactus & Toumeya papyracantha \\
\hline Wright's fishhook cactus & Neolloydia intertexta \\
\hline & Mammillaria wrightii \\
\hline
\end{tabular}

Table 3-1. Threatened and Endangered Species on KAFB

\subsection{Worker Environment}

Chemicals used in the GIF in association with dry cell operations include oils, household cleaners, silicone rubber, batteries, grease, rosin-core solder, light liquid petroleum, hydrogen peroxide, and cyanoacrylate ester. LICA operations would use similar substances with the addition of acetone; toluene; cutting fluids; various alcohols, adhesives, and pastes; compressed argon, helium, and neon; safety solvents; Freon TF; and sealants.

Test units brought into the facility for irradiation could contain hazardous materials in the form of batteries (lead, reactive metals, thionyl chloride), motors containing lubricants, etc. Release of these materials is extremely unlikely as long as the equipment containing them remains intact.

The LICA boiler uses condensate containing chromates, sodium metabisulfite, sodium sulfite, and cobalt sulfate. Exposure to the condensate is unlikely except during maintenance activities.

\subsection{Archaeological and Historical Resources}

An archaeological survey of the proposed site (Hoagland, 1990) indicated that no prehistoric, historic, or Native American cultural resources were located within the GIF site boundaries. While the survey was conducted with particular reference to the site of the Technology Support Center (TSC) Office/Light Laboratory/ 
Conference Center building, it also included a larger area encompassing the proposed GIF site. It notes that previous surveys of the area found no cultural resource sites recorded within a mile of the proposed construction site.

No sites currently listed on the National Register of Historic Places or the State Register of Cultural Properties or sites nominated to these registers are located on the proposed site.

The New Mexico State Historic Preservation Officer (SHPO) has concurred that the GIF, as proposed, would be unlikely to have any effect on prehistoric, historic, or Native American cultural resources. 
This page intentionally left blank. 


\subsection{ENVIRONMENTAL CONSEQUENCES}

In this section, environmental consequences are organized according to the proposed action and alternatives. Based on the documented absence of sensitive resources and/or the absence of a mechanism for impacts to workers, the public, or the environment, the following issues are not discussed in detail below:

- Biological Resources - A thorough biological survey was conducted during the summer and early fall of 1992 for an area encompassing all of TA III and some adjacent areas (Sullivan 1992). During September 1992, the survey team examined the proposed site for construction of the proposed TSC Office/Light Laboratory/Conference Center and GIF buildings. They conclude in the biological survey report that with respect to the proposed GIF site "it is unlikely that any rare, sensitive, or endangered plant species would occur in this small weedy site." Consultation letters from state and federal agencies concur that no federal or state plant or animal species of concern would be affected by the proposed action. Therefore, no impacts to biological resources are anticipated.

- Archaeological and Historical Resources - As discussed in Section 3.7, no archaeological and historical resources are involved; therefore, no impacts are expected. In the event that archeological or cultural artifacts were discovered during construction, construction activities would be stopped and the SHPO consulted before continuing.

- Noise - Noise would be limted to that produced by construction machinery during preoperational activities. No impacts are expected as a result of noise.

\subsection{Proposed Action}

\subsubsection{Pre-Operational Activities}

\subsubsection{Air}

Since the area to be disturbed under the proposed action during the construction phases of this project exceeds $3 / 4$ acre, DOE would be required to apply for and obtain a Bernalillo County Air Quality Control Board Top Soil Disturbance Permit. Watering of disturbed areas and suspension of earth-moving operations during high winds would be employed to control fugitive dust during construction. When complete, the site would be cleaned, graded, compacted, and landscaped to minimize wind and water erosion. Exhaust emissions from construction equipment would be expected during construction, but would be managed to minimize interference with air intakes for surrounding buildings, etc. Exhaust emissions from the construction equipment is expected to be well below the 100 tons/yr threshold for requiring a conformity analysis under 40 CFR Part 51.

\subsubsection{Water}

Some water would be used to control dust during construction activities. Any storm water generated during construction would be contained on site to avoid any oils or other materials related to construction machinery from migrating off-site. 
Portable toilets would be used and all waste disposed of in accordance with City of Albuquerque requirements. No impacts to surface or groundwater are expected to result from site preparation and construction activities.

Decommissioning the LICA would require disposal of approximately 152,165 liters (36,000 gallons) of treated wastewater from the LICA. Treated wastewater would be discharged into the sanitary sewer system only if radiation levels meet the current standards for such discharge. Therefore, no impacts to sanitary sewer systems are anticipated.

\subsubsection{Soils and Seismology}

Since the load bearing capacity of the soils at the GIF site is sensitive to water content, a combination of spread-type footings at least 20 feet below the surface and drilled, cast-in-place concrete piers would be used in the building foundation (AGRA 1992). In addition, site grading would be designed to direct water away from the building and keep the subsoil dry. Impacts to soils are expected to be minimal.

The new GIF would be designed according to the provisions of DOE Order 5480.28 (DOE 1993), DOE Draft Standard 1020, the Uniform Building Code (UBC 1991) and University of California Research Laboratory publication UCRL 15910 (UCRL 1990). In particular, UCRL 15910 requires both static and dynamic calculation of seismic, wind, and flooding loads as part of the engineering design of the building. To aid in the design process, UCRL 15910 includes specific design parameters for the seismic environment at Sandia/New Mexico. Because of this conservative approach to facility design, breach of radiation containment or other serious damage from seismic causes is extremely unlikely.

\subsubsection{Impacts to Workers}

Transportation of equipment and materials to their new location from existing locations would be accomplished in accordance with MSDSs and Sandia guidelines, as well as appropriate state and Federal standards.

Source elements (also called "source pins") are composed of ${ }^{60} \mathrm{Co}$ sealed in cylindrical, stainless-steel canisters. These elements would be transferred to shipping containers under water in the GIF and LICA shield pools. Therefore, exposure of workers to radiation during this operation would be equivalent to their exposure during normal operations of the facilities (see Section 4.1.2, Normal Operations, below). During loading and unloading operations, two technicians and a radiation protection monitor would be employed. Federal regulations (10 CFR 71) require the maximum dose rate at the outside surface of the shipping container to be less than 200 mrem per hour. At 2 meters from the surface, the dose rate must be no greater than $10 \mathrm{mrem}$ per hour. Assuming that only the transport vehicle driver and the loading and unloading personnel would be within 2 meters of the shipping container and given a period of exposure to this level of radiation of 4 
hours per shipment, the total dose would be a maximum of $1.6 \times 10^{-1}$ person-rem. (A person-rem is a unit used to estimate the dose from radiation to a population. The population dose in person-rem is equal to the average individual dose times the number of people exposed in a population.) Based on an occupational risk factor of $4 \times 10^{-4}$ fatal cancers per person-rem (NRC 1991; DOE 1993), workers engaged in this proposed action would not incur any harmful health effects from radiation exposures they receive during accident-free transportation of sources.

Actual exposure levels would likely be far less than the maximum assumed in the preceding paragraph. In recent experience, transfer of source elements was accomplished with no measurable dose to personnel (SNL 1993).

\subsubsection{Impacts to the Public}

No change in impacts to the general public are expected from pre-operational activities.

\subsubsection{Normal Operations}

\subsubsection{Air}

Production of ozone under the proposed action would be about the same as under the no-action alternative (i.e., 400 grams ( 14 ounces) per year as discussed in Section 4.2.1, below), since the source size and expected experimental mix would be approximately equal in the two alternatives. The amounts and form of hazardous gases and chemicals would be the same as in the no-action alternative; that is, none would be present except as components of experimental articles.

\subsubsection{Water}

As discussed in Section 2.1.2, no releases of water containing contaminants above regulatory limits are expected. Little or no change in the amount of water used during operations is anticipated. Based on this information, no impact to water resources is expected to result from normal operations at the new GIF.

\subsubsection{Soils and Seismology}

The new GIF facility would be built to withstand any reasonably foreseeable seismic event, as discussed in section 4.1.1.3. Therefore, normal operations would be essentially unaffected by seismic events. Normal operations do not involve soil disturbance; therefore, no impacts to soils are expected to result from the proposed action.

\subsubsection{Impacts to Workers}

Exposures resulting from skyshine are included in the worker dose estimates presented in Table 4-1. Skyshine is the reflection of radiation from the free air space and structural components above the sources. When sources are submerged 
there is no direct radiation and no skyshine. When sources are raised into the cells for an irradiation, the roof of the facility has slightly higher radiation fields than the floor due to the fact that the ceiling of the cell is slightly thinner than the walls (1.4 meters versus 1.8 meters). The maximum dose rate at the roof is $3.2 \mathrm{mrem} / \mathrm{hr}$, of which a small amount is reflected to the floor level.

Installing the existing GIF and LICA sources in a new facility may provide reduction of doses to personnel over the no-action alternative. By removing the ACRR source term, doses to individuals at the new GIF are reduced. However, due to improved capabilities, the utilization of the facility is expected to increase and doses may also increase. The net effect is therefore dependent on the facility utilization, and this can only be conservatively assumed for this discussion.

The design of the new GIF will comply with ALARA criteria; therefore, all doses are expected to be as low as reasonably achievable. The design further assumes very conservative values for source strength (250 and 500 kiloCuries [kCil), utilization factor $(100 \%)$, and personnel residence time $(50 \%)$. Based on these assumptions, maximum dose rates at the outside of the cell walls are predicted to be $1 \mathrm{mrem} / \mathrm{hr}$, maximum. Some localized dose rates (cell roof, cell windows, maze door, etc.) may be higher, however, operators are not expected to be resident at these locations for any considerable time. There is no significant dose rate from sources at the pool bottom.

To obtain a more realistic determination of expected worker exposures, assumptions must be consistent with current operating characteristics. Using values of $10 \%$ utilization and $10 \%$ residence, an operator could obtain a dose of 20 $\mathrm{mrem} / \mathrm{yr}$ (dose due to LICA operations is not shown, since they would be combined with GIF operations). Worker doses under the proposed action are summarized in Table 4-1.

\begin{tabular}{|l|c|c|c|}
\hline Facility & Dose & Population & Total Dose/Yr \\
\hline ACRR & $39 \mathrm{mrem}$ & 7 & $273 \mathrm{mrem}$ \\
\hline GIF & $20 \mathrm{mrem}$ & 2 & $40 \mathrm{mrem}$ \\
\hline
\end{tabular}

Table 4-1. Worker Doses Under the Proposed Action

Since workers in the proposed new GIF would receive less measurable dose per person than in the existing facilities, the potential for adverse health effects would be less. No dose to uninvolved workers or the public outside the facilities would be expected.

Assuming a facility life of 40 years, the cumulative worker dose would be 1.6 person rem. Based on an occupational risk factor of $4 \times 10^{-4}$ fatal cancers per person rem, workers engaged in operations of the proposed GIF would not be 
expected to incur any harmful health effects from radiation exposures they receive during normal operations.

The provisions for safe use of chemicals described for No Action and Upgrade Existing Facilities apply to the Proposed Action as well.

Additional controls on the maximum quantities of chemicals stored and used in the GIF would be imposed administratively in accordance with the provisions of the UBC, which governs the design of the facility.

\subsubsection{Impacts to the Public}

No releases, other than minute quantities of ozone, would occur under the proposed action. Therefore, no impacts to the public are anticipated to result from normal operations.

\subsection{Alternative 1: No Action}

The no-action alternative involves no pre-operational activities, such as grading, construction, facility upgrades, or transportation of sources to TA V. Therefore, only impacts related to normal operations are discussed in this section. Impacts related to accidents are discussed in Section 4.4.

\subsubsection{Air}

The major air quality impacts due to operation of the existing GIF involve production of ozone by gamma irradiation of air. No ozone is produced when the gamma source is stored in its shield pool. Therefore, the amount of ozone produced by an individual experiment is difficult to predict, since it depends on the size of the gamma source and the duration of exposure, both of which can be varied by GIF experimenters. Ozone is released to the atmosphere by diffusion and by forced ventilation of the experimental cells. The total amount of ozone released to the atmosphere was estimated at 400 grams (14 ounces) during calendar year 1994 (Bryson 1994). Ozone decomposes rapidly in air (Rao 1992) and thus is unlikely to develop hazardous concentrations outside the GIF building.

No other hazardous gases or chemicals with hazardous vapors are used in the GIF except as discussed in Section 3.6, and no releases are expected during normal operations. Based on the small quantity of ozone released and the absence of other potential contaminants, no impacts to air quality are expected to result from the noaction alternative.

\subsubsection{Water}

Normal operations conducted under the no action alternative will not result in any change in water use or any release of water to sewage systems in excess of regulatory standards. Therefore, no impacts to water use or quality are anticipated. 


\section{2 .3 Soils and Seismology}

The design of the GIF building structure (ACRR highbay and crane) has been analyzed for seismic response. The ACRR unreinforced block walls are a relatively weak component of the facility. An earthquake of Richter magnitude 5 to 6 is known to cause damage to unreinforced masonry walls. Conservative assumptions were used in this calculation to determine approximate stress levels. The penthouse crane structure will survive a $0.22 \mathrm{~g}$ design basis earthquake per UCRL 15910 requirements as long as the ACRR block wall remains intact. Another relatively weak component of the penthouse framed structure is the vertical tie rods (safety margin $=3.8$ ) when subject to a north-south earthquake. This corresponds to a $0.836 \mathrm{G}$ design basis earthquake and a best-estimate return period greater than 10,000 years.

No seismic analysis exists for the GIF cells or pool.

Seismic capacity has been calculated for the existing LICA pool in Building 867. A conservative estimate of the median capacity due to excessive deformation of the pool wall and tearing of the steel liner was determined to be $3.1 \mathrm{~g}$. By integrating this fragility over hazard curves applicable to the Sandia site, the mean probability of failure was determined to be $7.1 \times 10^{-8}$, which is well below exceedance probabilities required by the DOE. Based on this information, no impacts to normal operation are expected to result from reasonably foreseeable seismic disturbances. Because no construction or land-disturbing activities are involved, no impacts to soils would result from normal operations conducted under the no-action alternative.

\subsubsection{Impacts to Workers}

Radiation sources in the current GIF consist of about $9.3 \mathrm{PBq}(250 \mathrm{kCi})$ of ${ }^{60} \mathrm{Co}$. The radioactive material is encapsulated in sealed, stainless-steel tubes and is continuously shielded either by a water pool or by specially designed shield walls to prevent personnel exposure. Because the radioactive materials are encapsulated, no radioactive materials would be released into the occupied building spaces or the water in the shield pool.

Sandia has successfully operated these facilities by means of careful adherence to standards (refer to Safe Operating Procedures for the Gamma Irradiation Facility in Room 110, BIdg. 6588, SNL 1990, and Safe Operating Procedures for LICA, SNL 1988). Worker radiation exposure during normal operations is limited by DOE Orders as well as Federal and state regulations. Exposure levels in the GIF are monitored continuously by individual dosimeters. During operations with the potential for increased exposure, such as moving source elements, etc., personnel from the Sandia Radiation Protection organization are present to monitor dosages.

Mandatory safety reviews of experiments and operations require careful evaluation of the potential for a release from all activities. As a result of this safety review, 
restrictions or modifications of experiment design may be required to minimize or eliminate the risk of a release to the environment. For example, restrictions may be placed on stored energy or source size, or modifications to containment design may be required. During normal operations with radioactive targets, no radioactive byproducts are released.

Operational doses to ACRR, GIF, and LICA personnel (based on calendar year 1991 dosimetry data collected by Sandia's Personnel External Radiation Program) are given in Table 4-2.

\begin{tabular}{|l|c|c|c|}
\hline Facility & Individual Dose & Population & Total Dose $/ \mathrm{Yr}_{\mathrm{r}}$ \\
\hline ACRR & $39 \mathrm{mrem}$ & 7 & $273 \mathrm{mrem}$ \\
\hline GIF & $30 \mathrm{mrem}$ & 1 & $30 \mathrm{mrem}$ \\
\hline LICA & $0 \mathrm{mrem}$ & 1 & $0 \mathrm{mrem}$ \\
\hline
\end{tabular}

Table 4-2. Worker Doses Under the No-Action Alternative

Assuming a facility life of 40 years, the cumulative worker dose would not exceed 24 person-rem. Based on an occupational risk factor of $4 \times 10^{-4}$ fatal cancers per person-rem, workers engaged operations of the existing GIF would not be expected to incur any harmful health effects from radiation exposures they receive during normal operations.

No dose to non-involved workers and the public outside the facilities is detectable.

4.2 .5 Impacts to the Public

No releases, other than minute quantities of ozone, would occur under the noaction alternative. Therefore, no impacts to the public are anticipated.

\subsection{Alternative 2: Upgrade Existing Facilities}

\subsubsection{Pre-Operational Activities}

\subsubsection{Air}

Interior demolition and construction activities would result in generation of small quantities of fugitive dust. Appropriate dust control measures would be instituted during these activities; therefore, no discernible impact to air quality would result.

\footnotetext{
${ }^{1}$ The estimated number of casual experimental workers in the proposed GIF would be 10, each working a maximum of one week per year. For the purposes of this EA, an upper bound for GIF operational personnel and experimenters is assumed to be one full-time equivalent person.
} 


\subsubsection{Water}

Since all construction would be inside existing structures, construction activities would be unlikely to affect water quality. Since an upgraded LICA facility would not be decommissioned, there would be no need to dispose of the pool water.

\subsubsection{Soils and Seismology}

Pre-operational activities would be limited to interior demolition and construction. No impacts to soils would result. While shielding upgrades would be designed according to applicable standards, the facilities would still be located in existing buildings with unknown seismic properties. The upgrades would not affect building design to the point of altering the structures' ability to withstand seismic events.

\subsubsection{Impacts to Workers and the Public}

No impacts to workers and the public are expected to result from pre-operational activities.

\subsubsection{Normal Qperations}

\subsubsection{Air}

Impacts on air quality in upgraded facilities would be the same as in the proposed action, since upgrading would include updated ventilation and control systems.

\subsubsection{Water}

Upgrading the existing GIF would not affect the connections to the existing sanitary sewer system and LECS. The LICA would not be connected to the LECS. Therefore, the impacts from normal operations would be the same as under the noaction alternative.

\subsubsection{Soils and Seismology}

Issues related to soils and seismology would be essentially identical to those related to the no-action alternative, discussed in Section 4.2.3. No discernible impacts would be anticipated.

\subsubsection{Impacts to Workers}

Installing additional shielding in the GIF/ACRR facility would reduce the dose to GIF personnel from ACRR activities. Operational doses under this alternative for GIF personnel, estimated by removing the ACRR source term from current dose averages, (based on calendar year 1991 dosimetry data collected by Sandia's Personnel External Radiation Program) are provided in Table 4-3.

Since workers in the GIF and LICA would receive no measurable dose, no adverse health effects would be expected. No dose to uninvolved workers or the public outside the facilities would be expected. 


\begin{tabular}{|l|c|c|c|}
\hline Facility & Individual Dose & Population & Total Dose/Yr \\
\hline ACRR & $39 \mathrm{mrem}$ & 7 & $273 \mathrm{mrem}$ \\
\hline GIF & $0 \mathrm{mrem}$ & $1^{2}$ & $0 \mathrm{mrem}$ \\
\hline LICA & $0 \mathrm{mrem}$ & 1 & $0 \mathrm{mrem}$ \\
\hline
\end{tabular}

Table 4-3. Worker doses under the upgrade facilities alternative.

\subsubsection{Impacts to the Public}

Normal operations conducted under this alternative would not result in any release other than 400 grams (14 ounces) per year of ozone. Due to the minute quantity of ozone released, impacts to the public as a result of this alternative are not expected.

\subsection{Accidents}

\subsubsection{Worker Exposure to Ozone}

Accidental exposure to ozone could occur if personnel entered the exposure cell before ozone levels have dropped to safe concentrations. This could be due to undetected failure of the ventilation system, operator error in opening the cell door before the prescribed time delay has elapsed, or both.

The probability of accidental exposure is reduced by ventilation status indicators at the operator's position and administrative controls that prevent entry to the cells for a specified time after the source is removed. Emergency procedures require the source to be lowered into the shield pool and operation of the ventilation system to be verified if the odor of ozone is detected outside the cell (SNL 1990).

The mechanism and consequences of exposure to ozone would be the same for the proposed action and the upgrade facilities alternative as for the no-action alternative. The probability of such an accident would be reduced further by engineering controls for the proposed gamma irradiation cells, which would include interlocks that would prohibit opening the cell doors for 10 minutes after lowering the source into the shield pool to allow ozone levels in the cell to return to safe levels.

The controls would also lower the source automatically if differential pressure sensors indicated failure in the ventilation system. Administrative procedures requiring evacuation if the odor of ozone were present outside the cell would remain in place.

\footnotetext{
2 The estimated number of casual experimental workers in the proposed GIF would be 10, each working a maximum of one week per year. For the purposes of this EA, an upper bound for GIF operational personnel and experimenters is assumed to be one full time equivalent person.
} 
Exposure to ozone in high concentrations causes irritation of eyes, nasal passages, and lung tissue in personnel who breathe the gas. The threshold limit value (TLV) for ozone, defined as the maximum concentration to which workers can be exposed continuously without irritation or injury, is 0.1 parts per million $(\mathrm{ppm})$. The short term exposure limit (STEL), which is defined as the maximum airborne concentration of ozone to which workers can be exposed to continuously for a short period of time (defined by the Occupational Safety and Health Administration as 15 minutes) without suffering from irritation, chronic or irreversible tissue damage, or narcosis of sufficient degree to increase the likelihood of accidental injury, is $0.3 \mathrm{ppm}$. Ozone is detectable by its odor at levels considerably smaller than the TLV. Because the quantity of ozone generated by an individual test would be relatively small, and the ozone would dissipate rapidly into the high bay atmosphere, it is unlikely that workers would be exposed to high concentrations for an extended time; therefore, it appears likely that effects would be limited to temporary irritation of eyes, nasal passages, and lung tissue in the unlikely event that exposure occurred.

\subsubsection{Worker Exposure to Radiation}

For the GIF, the highest-risk accident scenario for workers are those associated with direct exposure to radiation from the gamma sources in the inhabited GIF area. This would occur if the gamma source were raised into operating position with the cell shield doors open or if the shield doors were opened with the source still in operating position. Exposure to the full source would almost certainly be fatal to personnel inside the cell or near the cell with an unshielded line of sight to the source. Exposure to a single source pin (about $10 \mathrm{kCi}$ ) is a more probable occurrence due to the occasional, underwater movement of source pins. This procedure is performed manually by an operator using long $1>3$ meters or approximately 10 feet) source handling tools. An operator error could result in the submerged pin being lifted out of the water and the operator being directly exposed to the source. The dose rate at 3 meters (10 feet) from a single source pin is less than $0.4 \mathrm{rems} / \mathrm{second}$. Although this is a very high radiation field, the operator has almost 12 seconds to evacuate the area or find a shielded location before the DOE annual radiation limit of 5 rems is exceeded. Therefore, the GIF accident analysis postulates that an operator could take mitigating action before receiving an injurious dose. These types of accidents could occur only upon failure of shielding, failure of controls and interlocks, and/or disregard for numerous administrative controls which define the safe operating procedures for the facility.

The probability of exposure of GIF personnel to radiation from the gamma sources in the inhabited area (that is, all areas outside the experimental cells) is approximately the same for all three alternatives. Interlocks would prohibit opening the cell doors with the source in place, so in order for personnel to be exposed, interlocks and administrative controls would have to fail. Automatic controls would cause the source to be lowered into the shielding pool upon indication of any abnormal conditions. Conditions that would lead to lowering the source include: 
- Detection of heat or smoke in the cell

- Failure of primary electrical power for more than 10 seconds

- Loss of power to the access control system

- Loss of ventilation in the cell

- Removal of the key used to activate the source control system

- Opening of the personnel door interlocks.

Control and interlock mechanisms in the new GIF would be marginally more reliable than in the no-action alternative, since they would use current designs and components.

In the event of an accident, radiation area monitors (RAMs) would activate alarms, warning personnel of the accident so they could evacuate to a safe area. Radiation would not be released to the environment, since the radioactive material would remain inside the facility (Boldt 1993). Note that the SOP for the existing GIF includes the possibility of release of radioactive materials to the environment because of the presence of the ACRR in the same facility. Therefore, safe operation of the GIF requires coordination with ACRR systems and personnel. There would be no mechanism for such a release resulting from GIF operations under the proposed action.

The collective dose due to accidental radiation exposure is lower in the proposed action than in the other alternatives due to the smaller number of operational personnel in the area. This is because the new GIF would be removed from the vicinity of the ACRR and its operating personnel. Therefore, only one person, the GIF operator, would inhabit the building on a full-time basis. Experimental personnel would be in the building only during the time they are actually setting up or dismantling experiments.

\subsubsection{Source Rupture}

In the event that radioactive material were to be accidentally released into the GIF pool, for example from the rupture of a cobalt source pin, RAMs monitoring the activity in the water-circulating system would activate alarms, indicating the presence of radioactive material in the water. The radioactive material would remain in the GIF pool water and would not be released to the environment. The radioactive material would be trapped in the ion exchange resins through which the pool water is circulated continuously. The resins would be disposed of as radioactive solid waste in a permitted disposal facility off-site. The pool water (approximately 84,000 gallons) would be monitored for radiation to determine whether it could be disposed of in the sanitary sewers in accordance with applicable Federal, state, and local regulations. If the radiation levels are within acceptability standards for the sanitary sewer system, the water would be disposed of as sanitary sewerage. If, on the other hand, radiation levels were too high to meet standards for disposal in the sewer, the water would be treated in an 
appropriate manner (e.g. by evaporation or solidification) and the radioactive material would be disposed of as solid radioactive waste.

No releases of contaminated water would result from this accident scenario. Some radioactive waste could be generated if treatment of the water is required; however, the waste would not be released into the environment. Therefore, no impacts are anticipated to result in the event that this accident would occur.

\subsubsection{Accidents Considered But Not Discussed In Detail}

Exposure of the public to the maximum unshielded source of $1500 \mathrm{kCi}$ is not considered credible due to the location of the sources and the process by which sources are used. Sources are located at the bottom of a 5.5 meter deep pool of water with the top of the pool at ground level. Even if all of the water were gone from the pool, the below-ground level of the sources would prevent exposure to the public. To irradiate experiments in the cells, sources are raised from the pool by elevators. The elevators (one for each small cell and two for the large cell) can only reposition sources between the pool and the cells and are not capable of locating the source above the pool surface outside of the shielded cell walls. Therefore, this accident is not considered credible. As a point of reference, the dose rate at 3,000 meters (1.8 miles) from an unshielded $1500 \mathrm{kCi}$ source would be approximately $2.8 \mathrm{E}-5 \mathrm{mrem} / \mathrm{hr}$. The 3,000 meter $(1.8 \mathrm{mile}$ ) distance is the closest general public access to TA-V along the west boundary of Kirtland Air Force Base.

Breach of shielding due to facility damage in an earthquake or other natural disaster is not considered credible, since the GIF facility would be designed in accordance with the guidelines of DOE Order 5480.28, UCRL 15910 and other applicable codes and standards.

The environmental statement prepared by the Nuclear Regulatory Commission concerning shipment of radioactive materials (NRC 1977) calculates the dose to the public from various types of accidents involving transport of radioactive materials. The Population Dose Commitment from a Category VIII (worst case) accident involving $315,000 \mathrm{Ci}$ of Cobalt 60 in a DOT Class B shipping container is 284 person-rem. This assumes high urban population density $(3,861$ persons per square kilometer) in the area surrounding the accident. Under these assumptions, such a dose would be expected to cause 0.1 (in other words, less than one) latent cancer death. Since the amount of material to be transported in the proposed action is not as large as that used in the accident calculations and the population density over most of the transport route is much smaller than that in the estimate, this can be considered a conservative estimate of the impact of an accident under the proposed action. However, as detailed in the description of the proposed action, a number of new and replacement sources are expected to be acquired for the GIF. Therefore, over the 40-year facility lifetime, 10 to 40 separate shipments can be expected. The probability of such an accident for each shipment is estimated in the NRC environmental statement at approximately $1 \times 10^{-10}$. Even 
with the maximum number of expected shipments, the overall probability for the accident is considered incredible and therefore is not analyzed in detail here.

\subsection{Cumulative Impacts}

Cumulative impact is the impact to the environment which results from the incremental impact of the proposed action when added to other past, present, and future actions regardless of what agency or person undertakes such action (40 CFR 1508.7). The cumulative impact is the sum of impacts from the activities at the GIF plus activities at other nuclear facilities within TA-V. At present four nuclear facilities are expected to be operating in TA-V in the foreseeable future:

1. New Gamma Irradiation Facility (GIF) proposed in this activity

2. Annular Core Research Reactor (ACRR)

3. TA-V Hot Cell Facility (HCF)

4. Sandia Pulsed Reactor (SPR)

The ACRR and HCF are being proposed for use in the production of medical isotopes, which is being evaluated in a separate NEPA document. The assessment presented here assumes that the isotope production activity would be in operation at $200 \%$ of U.S. demand for ${ }^{99} \mathrm{Mo}$ and the that SPR would remain in a routine operation mode.

\subsubsection{Cumulative Operations Impact for the Public}

Cumulative impact for the public from normal operations and accident conditions includes all aspects of the proposed activity plus the contribution form other TA-V nuclear facilities:

\section{Proposed GIF Operations}

- Operation and experimentation for in-cell dry irradiation facilities

- Operation and experimentation for in-pool wet irradiation facilities

- Transportation of sources

Other TA-V Nuclear Facilities

- Annular Core Research Reactor

- TA-V Hot Cell Facility

- Sandia Pulsed Reactor

There are no airborne radiation releases (planned or accidental) projected for the GIF which could impact the general public.

\subsubsection{Cumulative Operations Impact for GIF Workers}

The cumulative operations impact to workers includes impacts from GIF operations and impacts from the operations of other nuclear facilities in TA-V. Because the GIF operations staff are separate from the operations staff of other nuclear facilities 
in TA-V, doses for individual workers are not additive; however cumulative doses for the worker population are additive. The radiological impacts from the GIF operations result from activities involved in the routine operation of the in-cell dry irradiation facilities, the in-pool wet irradiation facilities, and the Shepard Irradiation Facilities (a possible future addition). These facilities are described in Chapter 2.

The impacts to the TA-V worker population from other TA-V Nuclear facilities include the operations of the following facilities:

- Annular Core Research Reactor

- TA-V Hot Cell Facility

- Sandia Pulsed Reactor

As stated in Section 2.1 of this document, the new GIF would be designed to reduce doses from the existing facility for an equivalent operating profile. However, the new GIF will have many enhanced capabilities which, most likely, will result in increased usage. Increased usage could result in higher doses for normal operations and increased risk of accidental exposures for workers.

\subsubsection{Cumulative Impacts to the Environment}

The cumulative impacts to the environment occur from the anticipated release of radiological and chemical contaminants to the environment:

- Gaseous Emissions - The only gaseous emission from the operation of the new GIF is the production and release of ozone at a rate of up to 400 grams (14 ounces) per year. The total quantity of ozone is dependent on the amount of time a source is elevated out of the pool and into a dry cell.

- Liquid Discharges - The pool water for the new GIF may exhibit trace amounts of radioactive contaminants under normal operations. The trace amounts are concentrated by demineralizer beds, which are part of the pool water cleanup system. Discharges or spills of pool water are not anticipated; however if they occur, the effluent is collected in the TA V LECS. If the effluent meets standards for disposal in the sanitary sewer, it is released to the POTW. If the effluent does not meet release standards, the water would be processed through ion-exchange resins for decontamination to release levels. Larger amounts of pool contamination will occur if a source pin leaks or is ruptured.

- Solid Waste - Demineralizer beds, consisting of ion-exchange resins, are the only potential radioactive waste generated by normal operation of the new GIF. Trace amounts of radioactive contaminants may be concentrated in the resins. The resins would be disposed of as solid, low-level radioactive waste in a permitted, off-site disposal facility. Based the current GIF demineralizer usage and scaling for volume, the new GIF would generate from 800 to 1200 liters (189 to 284 gallons) of potentially-contaminated resins per year. 


\subsubsection{Summary of Cumulative Impacts}

A summary of the estimated impacts for all radiation exposures is presented in Table 4-4. For cumulative impacts these values are summed with the impact from all other TA-V nuclear facilities. The GIF operations would therefore add 0.000012 LCFs to the total impact for TA-V.

\begin{tabular}{|l|c|c|c|c|}
\hline \multirow{2}{*}{$\begin{array}{l}\text { Numulative Impacts from } \\
\text { Normal Operations }\end{array}$} & \multicolumn{2}{|c|}{$\begin{array}{c}\text { General Population } \\
\text { Exposure }\end{array}$} & \multicolumn{2}{c|}{$\begin{array}{c}\text { Worker Population } \\
\text { Exposure }\end{array}$} \\
\cline { 2 - 5 } & $\begin{array}{c}\text { Dose } \\
\text { (Person Rem) }\end{array}$ & $\begin{array}{c}\text { Impact } \\
\text { (LCF) }\end{array}$ & $\begin{array}{c}\text { Dose } \\
\text { (Person Rem) }\end{array}$ & $\begin{array}{c}\text { Impact } \\
\text { (LCF) }\end{array}$ \\
\hline GIF Operations & & & & \\
- Operation of in-cell facilities & 0.0 & 0.0 & 0.03 & $1.2 \mathrm{E}-5$ \\
- Operation of in-pool activities & 0.0 & 0.0 & 0.0 & 0.0 \\
Total & 0.0 & 0.0 & 0.03 & $1.2 \mathrm{E}-5$ \\
\hline Other TA-V Nuclear Facilities & & & & \\
- ACRR in Isotope Production & 15.5 & $7.8 \mathrm{E}-3$ & 10 & $4.0 \mathrm{E}-3$ \\
- HCF in Isotope Production & 147 & $7.4 \mathrm{E}-2$ & 17.7 & $7.1 \mathrm{E}-3$ \\
- SPR in Normal Operation & $6.2 \mathrm{E}-3$ & $3.1 \mathrm{E}-6$ & 3.6 & $1.4 \mathrm{E}-3$ \\
Total & 162.5 & $8.2 \mathrm{E}-2$ & 31.3 & $1.3 \mathrm{E}-2$ \\
\hline Total for All TA-V Facilities & $\mathbf{1 6 2 . 5}$ & $\mathbf{8 . 2 E - 2}$ & $\mathbf{3 1 . 3}$ & $1.3 \mathrm{E}-2$ \\
\hline
\end{tabular}

Table 4-4. Summary of Estimated Annual Cumulative Impacts

\subsection{Environmental Justice}

On February 11, 1994, Order 12898, "Federal Actions to Address Environmental Justice in Minority populations and Low-Income Populations" was published in the Federal Register (59 FR 7629). A NEPA document should identify the minority and low-income communities that may experience a disproportionately high impact resulting from the proposed action.

Relocation of the GIF and LICA and operation of the new facility are not expected to result in any measurable off-site impacts. Therefore, no minority or low-income communities would be impacted by the proposed action.

\subsection{Air Conformity}

40 CFR 93 requires that Federal actions conform to State Implementation Plans (SIPs) formulated under the Clean Air Act. The conformity regulations provide "threshold values" below which the regulations do not apply. The proposed action is not expected to result in air emissions other than the 400 grams (14 ounces) of

\footnotetext{
${ }^{3}$ Assumes 10 workers at the ALARA dose level of $500 \mathrm{mrem} / \mathrm{yr}$
} 
ozone and minor fugitive dust from site grading activities. These emissions are well below the threshold values given in the regulations. Similarly, emissions from construction equipment are expected to be well below the 100 tons/yr threshold for carbon monoxide specified in the regulations; therefore, the proposed action would not result in the violation of air conformity requirements. 


\subsection{PERSONS AND AGENCIES CONSULTED}

The following government agencies and personnel were contacted during the preparation of this EA:

- $\quad$ Anne Cully

U.S. Department of the Interior

Fish and Wildlife Service

Ecological Services

Albuquerque, NM

- Bob Silver

New Mexico State University

Physical Sciences Laboratory

Las Cruces, NM

- State of New Mexico

Energy, Minerals and Natural Resources Department

Santa Fe, NM 87505 
This page intentionally left blank.

DOE/EA - 0973 


\subsection{LIST OF ACRONYMS AND ABBREVIATIONS}

$\begin{array}{ll}\text { ACRR } & \text { Annular Core Research Reactor } \\ \text { ALARA } & \text { As low as reasonably achievable } \\ \text { Bq } & \text { Bequerel (SI unit of radioactivity) } \\ \text { Ci } & \text { Curie (customary unit of radioactivity) } \\ { }_{60} \text { Co } & \text { Cobalt-60 } \\ { }^{137} \text { Cs } & \text { Cesium-137 } \\ \text { DoD } & \text { U. S. Department of Defense } \\ \text { DOE } & \text { U. S. Department of Energy } \\ \text { DOT } & \text { U. S. Department of Transportation } \\ \text { E } & \text { E is used in scientific notation to represent "x } 10 \text { to the power } \\ & \text { of.." For example, "1.2E-2" is the same as "1.2 } \times 10^{-2} \text { " } \\ \text { EA } & \text { Environmental assessment } \\ \text { ERDA } & \text { Energy Research and Development Administration } \\ \text { ES\&H } & \text { Environmental, safety, and health } \\ \text { GIF } & \text { Gamma Irradiation Facility } \\ \text { HCF } & \text { Hot Cell Facility } \\ \text { KAFB } & \text { Kirtland Air Force Base } \\ \text { KCi } & \text { Kilocurie (10 }{ }^{3} \text { Curie) } \\ \text { KUMSC } & \text { Kirtland Underground Munitions Storage Complex } \\ \text { LECS } & \text { Liquid effluent control system } \\ \text { LICA } & \text { Low-Intensity Cobalt Array } \\ \text { MCi } & \text { Megacurie (10 }{ }^{6} \text { Curie) } \\ \text { 99Mo } & \text { molybdenum-99 } \\ \text { mrem } & \text { Millirem } \\ \text { MSDS } & \text { Material Safety Data Sheet } \\ \text { NEPA } & \text { National Environmental Policy Act } \\ \text { PBq } & \text { Petabequerel (10 }{ }^{15} \text { Bequerel) } \\ \text { POTW } & \text { Publicly operated treatment works } \\ \text { RAM } & \text { Radiation area monitor } \\ \text { SHPO } & \text { State Historical Preservation Officer } \\ \text { SNL } & \text { Sandia National Laboratories } \\ \text { SNM } & \text { Special nuclear material } \\ \text { SOP } & \text { Standard Operating Procedure } \\ \text { SPR } & \text { Sandia Pulsed Reactor } \\ \text { TA } & \text { Tech Area } \\ \text { TSC } & \text { Technology Support Center } \\ & \end{array}$


This page intentionally left blank. 


\subsection{REFERENCES}

AGRA 1992 Geotechnical Investigation Report, Sandia National Laboratories Technology Support Ceneter Soil Testing Services, SHB AGRA, Inc., December 18, 1992.

Boldt 1993

K.R. Boldt, Gamma Irradiation Facility (GIF) Basis for Interim Operation, Nuclear Facility Safety and Development Department, Sandia National Laboratories, September 30, 1993.

Boldt 1995

Kenneth R. Boldt, Sharon A. Walker, and Michael D. Olbin, Preliminary Safety Analysis Report for the Gamma Irradiation Facility, March 1995.

Bryson 1994

DOE 1993

ERDA 1977

Fischer 1990

Hoagland 1990

NMAQB1984

NRC 1977

Rao 1992
Memo, J.W. Bryson to R.F. Matthews, November 28, 1994.

DOE Order 5480.28, “Natural Phenomena Hazards Mitigation," January 15, 1993.

Environmental Impact Assessment, Sandia Laboratories, Albuquerque, Energy Research and Development Administration, Division of Military Applications, May 1977.

N.T. Fischer, Revision of Species Inventory Checklists for Sandia National Laboratories, Albuquerque, Bernalillo County, New Mexico, SAND90-7098, Sandia National Laboratories, October 1990.

Letter from Steven R. Hoagland to Carlos Medrano, July 16, 1990 describing the results of the June 1990 archaeological survey of TA-V and TA-III.

Annual Report, 1983 and 1984, New Mexico Air Quality Bureau.

Final Environmental Statement on the Transportation of Radioactive Material by Air and Other Modes, NUREG-0170. U. S. Nuclear Regulatory Commission, December 1977.

D.V. Rao, Ventilation Requirements for Gamma Irradiation Facility, Report \#HP-TA5-002, Rev. A. Sandia National Laboratories, New Mexico Health Physics Department 7713, May 8, 1992. 
SHPO 1990

Sanford 1972

SNL 1988

SNL 1990

SNL 1991a

SNL 1991b

SNL 1993

Sullivan 1992

UBC 1991

UCRL 1990
Determination of No Effect on Historic Properties (letter from Thomas Merlan to Thomas B. Hyde, DOE/AL), State of New Mexico Historic Preservation Officer, September 26, 1990.

A.R. Sanford, A.J. Budding, J.P. Hoffman, O.S. Alptekin, C.A. Rush, and T.R. Topozada, "Seismicity of the Rio Grande Rift in New Mexico," Circular 120. New Mexico Bureau of Mines and Mineral Resources, Socorro, New Mexico, 1972.

Safe Operating Procedure for the Division 6447 Low Intensity Cobalt Array (LICA) Facility Located in Building 867, North End, Area I. Sandia National Laboratories, Division 6447, August 4, 1988.

Safe Operating Procedures for the Gamma Irradiation Facility in Room 110, Bldg. 6588, Sandia National Laboratories, Division 6454, February 1, 1990.

Environment, Safety, and Health Manual, Sandia National Laboratories, Albuquerque, New Mexico and Livermore, California, May, 1991.

Guidelines for Wastewater Discharges for Sandia National Laboratories (draft), Hazardous Waste and Wastewater Division 3221, Sandia National Laboratories, Albuquerque, New Mexico, May 1991.

GIF WESF Capsule SV-34 Loading Procedures, Procedure No. GIF-TPO-01. April 30, 1993.

R.M. Sullivan and P.J. Knight, Biological Surveys for the Sandia National Laboratories Coyote Canyon Test Complex, Kirtland Air Force Base, Albuquerque, New Mexico, Physical Science Laboratory, September 30, 1992 (Draft).

Uniform Building Code. International Conference of Building Officials, Whittier, CA, 1991.

Design and Evaluation Guidelines for Department of Energy Facilities Subjected to Natural Phenomena Hazards, UCRL 15910. University of California Research Laboratory, June 1990. 
Water Resources Data for New Mexico, Water Year 1976. Water-Data Report NM-76-1, U. S. Geological Survey. 